\title{
ANALISIS TADBIR URUS MAJLIS PERBANDARAN JASIN: IMPLIKASINYA TERHADAP KUALITI HIDUP PENDUDUK DARI PERSPEKTIF MAQĀṢID AL-SHARI'AH
}

\section{An Analysis on the Governance of Jasin Local Authority: Its Implication Towards Population Quality of Life from the Perspective of Maqāșid al-Sharī'ah}

\author{
Muhammad Hafiz Ibrahim ${ }^{1}$ \\ Mohamad Zaidi Abdul Rahman² \\ Osman Md Rasip ${ }^{3}$
}

\begin{abstract}
Governance is an important thing for Local Authority to ensure resident's life in good condition at their administration area. In this study, the Researcher used the quality measure of life from the Malaysian Quality of Life Index 2011 such as housing, environment, health, safety and transportation \& communication to explore the impact of local government's administration on quality of life. The objective of this study is to detect the existence of elements of Maqāsid al-Sharī'ah in the quality of
\end{abstract}

1 Master Candidate, Department of Siasah Syari'yyah, Akademy of Islamic Studies, University of Malaya, 50603 Kuala Lumpur, ima170022@siswa.um.edu.my

2 Senior Lecturer, Department of Siasah Syari'yyah, Akademy of Islamic Studies, University of Malaya, 50603 Kuala Lumpur, mzaidi@um.edu.my

3 Senior Lecturer, Department of Siasah Syari'yyah, Akademy of Islamic Studies, University of Malaya, 50603 Kuala Lumpur, osmanrasip@um.edu.my 
life governance of Jasin Municipal Council, to study how the Jasin Municipal Council manage the quality of life of residents under its jurisdiction and to know the extent of Jasin Municipal Council on the issue of quality of life. this study uses a fully qualitative method through the analysis of interviews, documents and observations. Overall, this study shows that the quality and performance of Jasin Municipal Council's services can affect the quality of life population in its administrative area. Beside that, this study also shows Maqāsid al-Sharī'ah should be given a priority on each of their action because Maqāṣid al-Sharī'ah is an objective to better of life.

Keywords: governance, quality of life, Jasin Municipal Council, Maqāṣid al-Sharī'ah

\section{PENGENALAN}

Dalam Islam, kuasa pemerintahan dan pentadbiran adalah merupakan amanah dan pemerintah dikehendaki melaksanakan tugas berdasarkan tanggungjawab yang diamanahkan secara individu dan secara kolektif. Sebagaimana firman Allah SWT:

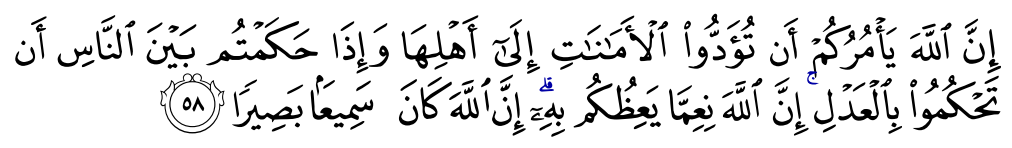

"Sesungguhnya Allah menyuruh kamu supaya menyerahkan segala amanah kepada ahlinya (yang berhak menerimanya) dan apabila kamu menjalankan hukum antara manusia, (Allah menyuruh) kamu menghukum dengan adil. Sesungguhnya Allah dengan (suruhanNya) itu memberi pengajaran yang sebaikbaiknya kepada kamu. Sesungguhnya Allah sentiasa Mendengar, lagi sentiasa melihat."

(Surah al-Nisā', 4: 58)

Pemerintah bertanggungjawab untuk melaksanakan tugas dan merealisasikan matlamat negara menurut pandangan Islam yang terungkap dalam konsep "khilafah" iaitu hīrāsah al-dīn (melindungi agama) dan siyāsah al-dūny $\bar{a}$ (mengurus urusan keduniaan). ${ }^{4}$ Islam juga turut mementingkan

4 Abdul Samat Musa, 'Hak dan Tanggungjawab Rakyat dan Ulil Amri,' dalam Konsep dan Peranan Ulilamri di Malaysia, ed. Abdul Monir Yaacob dan Suzalie Mohamad (Kuala Lumpur: Penerbit Institut Kefahaman Islam Malaysia, 2004), 138 . 
kesejahteraan hidup umat Islam maka terhasillah prinsip-prinsip maqāșid al-sharīah. Prinsip-prinsip tersebut adalah merangkumi lima aspek iaitu menjaga agama, nyawa, akal, keturunan dan harta. Komponen penting yang terdapat di dalam maqāṣid al-sharī'ah tersebut membuktikan bahawa Islam adalah sistem hidup yang lengkap, komprehensif dan relevan pada bila-bila masa dan sudah pasti boleh dilaksanakan dalam apa juga urusan kehidupan. ${ }^{5}$ Sebagaimana firman Allah SWT:

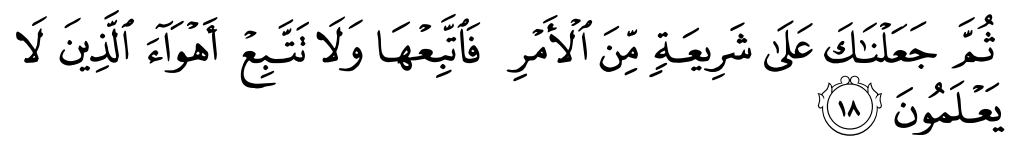

"Kesudahannya Kami jadikan engkau (wahai Muhammad dan utuskan engkau) menjalankan satu Syariat (yang cukup lengkap) dari hukum-hukum agama; maka turutlah Syariat itu dan janganlah engkau menurut hawa nafsu orang-orang yang tidak mengetahui (perkara yang benar).

(Surah al-Jāthiyah, 45: 18)

\section{KONSEP PIHAK BERKUASA TEMPATAN (PBT)}

Kerajaan Tempatan adalah merupakan satu pihak yang berkepentingan dalam menguruskan pentadbiran sesebuah kawasan dan ia terletak di bawah Kementerian Perumahan dan Kerajaan Tempatan (KPKT). Menurut Norain et al., ${ }^{6}$ konsep federalisme menjelaskan bahawa Kerajaan Tempatan atau Pihak Berkuasa Tempatan berbidangkuasa terhadap penyediaan perkhidmatan dan barang-barang tempatan. Secara umumnya, Kerajaan Tempatan merujuk sebuah konsep yang dianggotai oleh pihak berkuasa yang mentadbir sesebuah kawasan yang lebih kecil daripada sesebuah negeri dan ia merupakan kerajaan peringkat ketiga selepas Kerajaan Negeri dan Kerajaan Persekutuan atau Kerajaan Pusat. ${ }^{7}$ Peranan yang dimainkan oleh Kerajaan Tempatan

5 Jabatan Kemajuan Islam Malaysia, Indeks Syariah Malaysia: Model Tadbir Urus Berteraskan Maqasid Syariah (Putrajaya: Jabatan Kemajuan Islam Malaysia, 2015),51.

6 Norain Mod Asri, Zulkefly Abdul Karim, Norlaila Abu Bakar, Zafirah Husin, Harith Hasnan dan Idris Hamid, 'Pengurusan Fiskal Pihak Berkuasa Tempatan yang Berstatus Majlis Bandaraya di Zon Tengah Semenanjung Malaysia,' Jurnal Ekonomi Malaysia, vol. 52 (2018): 77-88.

7 Kamarudin Ngah dan Jamaludin Mustaffa, Ahli Majlis dan Kerajaan Tempatan (Kuala Lumpur: Dewan Bahasa dan Pustaka, 2012),36. 
merangkumi beberapa kuasa yang diperuntukkan, iaitu merujuk kepada Akta Kerajaan Tempatan 1976 (Akta 171), ${ }^{8}$ Akta Perancangan Bandar dan Desa 1976 (Akta 172) ${ }^{9}$ dan Akta Jalan, Parit dan Bangunan 1974 (Akta 133). ${ }^{10}$

\section{PENGERTIAN MAQT̄STID $A L-S H A R \bar{I}^{`} A H$}

Terdapat pelbagai definisi maqāṣid al-sharī'ah menurut pandangan beberapa tokoh ulama mutaqaddimīn dan muta'akhkhirīn antaranya ialah Ibn'Āshūr mendefinisikan maqāșid al-sharī'ah dalam konteks am dan khas iaitu maqāșid 'āmmah sebagai pengertian-pengertian dan hikmah-hikmah yang dititikberatkan dalam semua atau sebahagian perundangan Islam. Manakala maqāṣid khașșah sebagai metode-metode yang digunakan oleh shari' untuk merealisasikan objektif manusia untuk memelihara kepentingan umum. ${ }^{11}$ AlFāsī yang menyatakan bahawa maqāșid al-sharī'ah ialah matlamat, tujuan atau rahsia yang terkandung kepada sesuatu pensyariatan hukum. ${ }^{12}$ Manakala, al-Raysūn̄i, menyatakan maqāșid al-sharī'ah ialah sebagai matlamat yang ditentukan oleh syarak untuk dilaksanakan bagi memberikan kebaikan kepada hambanya. ${ }^{13} \bar{A}$ lim, Yūsuf Hamīd, menyatakan maqāșid al-sharī'ah itu adalah satu kebaikan yang kembali kepada hamba di dunia dan di akhirat sama ada dengan cara mendatangkan kebaikan atau menjauhkan kemudaratan. ${ }^{14}$ Manakala Wahbah al-Zuhaylī pula menyatakan bahawa maqāsid al-sharī'ah adalah nilai dan sasaran yang tersirat dalam segenap atau sebahagian terbesar dari hukum-hukumnya. ${ }^{15}$ Al-Yūbī pula menegaskan bahawa maqāșid alsharī'ah ialah makna, hikmah dan seumpamanya yang diambil kira oleh syarak dalam pensyariatan secara umum atau secara khusus dengan tujuan

\footnotetext{
$8 \quad$ Akta Kerajaan Tempatan 1976, (Akta 171).

9 Akta Perancangan Bandar dan Desa 1976, (Akta 172).

10 Akta Jalan, Parit dan Bangunan 1974, (Akta 133).

11 Ibn 'Āshūr, Muhammad al-Ṭāhīr, Maqāṣid al-Sharī'ah al-Islāmiyyah, (t.t.p.: alBașā’ir li al-Intāj al-'Ilmiyyah, 1998), 171.

12 Al-Fāsī, 'Alal, Maqāṣid al-Sharī'ah al-Islāmiyyah wa Makārimuhā (Rabat: Mațābi“ al-Risālah, 1993), 3.

13 Al-Raysūn̄̄, Nazariyat al-Maqāsid 'inda al-Imām al-Shātibī (Herndon: al-Ma'had al-'Alamī li al-Fikr al-Islāmī, 1995), 19.

14 'Ālim, Yūsuf Hamīd, al-Maqāṣid al-'Ammah li al-Sharī'ah al-Islāmiyah (alKharțūm: Dār al-Sudāniyyah, 1997), 97.

15 Wahbah al-Zuhaylī, Ușūl Fiqh al-Islāmī, vol. 2 (Dimashq: Dār al-Fikr, 1996), 1017.
} 
untuk memberikan kebaikan kepada manusia. ${ }^{16}$ Al-Qaraḍ̄āī mentakrifkan maqāșid al-sharī'ah sebagai hikmah yang menjadi tujuan ditetapkan hukumhukum yang disyariatkan Allah SWT untuk direalisasikan dalam hubungan manusia berbentuk perintah, larangan atau harus sama ada untuk individu, keluarga, bangsa dan umat. ${ }^{17}$ Yūsuf Aḥmad al-Baḍāwī dalam menyimpulkan maqāșid al-sharī 'ah adalah sebagai matlamat dan kehendak Allah SWT dalam syarak-Nya dan disukai oleh Allah SWT kerana ia mencerminkan perhambaan kepada-Nya dan Dia memberikan kebaikan kepada hamba-Nya di dunia dan akhirat. ${ }^{18}$

Berdasarkan kepada pentakrifan-pentakrifan di atas jelas, bahawa yang berbeza hanya dari segi lafaz, namun begitu tujuan syariat Allah SWT diturunkan adalah untuk merumuskan hukum-hukum Islam dengan mendatangkan kebahagiaan dalam urusan ummah dengan mengambil segala yang bermanfaat, menghindari segala bentuk unsur mudarat dan membersihkan dunia dari kejahatan atau dosa. Selain itu, didapati bahawa setiap peraturan ajaran Islam yang diturunkan oleh Allah SWT bertujuan untuk memberikan kebaikan kepada manusia atau menjauhkan mereka daripada keburukan. Dalam konteks ini maqāșid al-sharī'ah yang dimaksudkan ialah untuk menjaga matlamat, tujuan atau objektif tertentu daripada syariat Allah SWT agar umat manusia mendapatkan sesuatu perlindungan yang seadilnya.

\section{MAQĀṢID AL-SHARI'AH SEBAGAI PARAMETER}

Maqāșid al-sharī'ah digunakan sebagai pengukur dalam menilai setiaptindakan yang dilaksanakan oleh Majlis Perbandaran Jasin (MPJ) bagi mengatasi isuisu yang berkaitan kualiti hidup penduduk. Menurut Mohd Anuar Ramli et al., maqāșid al-sharī'ah dijadikan sebagai pengukur kerana ruang perbincangannya yang dilihat mudah dan banyak pihak mula menggunakannya sebagai

16 Muhammad Nazir Alias, 'Maqasid Syariah sebagai Sandaran Hukum Menurut Mazhab Syafie,' Journal of Islam and Civilization, vol. 2 (2018): 48-58.

17 Alias Azhar, 'Penyelidikan Fatwa dalam Kerangka Maqasid al-Syariah: Satu Tinjauan,' Journal of Islamic Sciences, vol. 20 (2017): 47-65.

18 Al-Baḍāwīi, Yūsuf Aḥmad Muhammad, Maqāṣsid al-Sharī'ah 'inda Ibn Taymiyyah ('Ammān: Dār al-Nafā'is, 2000), 52. 
kerangka analisis sama ada secara mendalam mahupun mendatar. ${ }^{19}$ Mohamad Zaidi juga bersetuju dengan menjelaskan bahawa, asas maqāșid al-sharī'ah boleh digunapakai sebagai kayu ukur dalam analisis terhadap sesuatu isu dan penggunaanya tidaklah sampai kepada tahap pembangunan indeks yang dilihat begitu kompleks. ${ }^{20}$ Dalam konteks ini, didapati parameter maqāșid al-sharī'ah dapat memberi petunjuk kepada tadbir urus MPJ bagi melihat kesungguhan mereka dalam melaksanakan amanah dan tanggungjawab mengikut landasan syariah Islam demi mencapai matlamat maqāṣid al-sharī'ah.

Di dalam kajian ini pengkaji hanya menyentuh tentang implikasi maqāṣid alsharī'ah daripada tindakan MPJ terhadap isu yang dihadapi penduduk dengan mengambil kira sesuatu yang mendatangkan kebaikan kepada penduduk terbanyak dianggap baik manakala tindakan yang akan mendatangkan kemudaratan harus ditolak bagi mencegah kerosakan yang lebih besar tanpa menyentuh secara terperinci berkaitan hukum atau nas syarak. Merujuk kepada Indeks Maqasid Syariah, salah faham mengenai syariah Islam disebabkan pemahaman singkat sesetengah masyarakat yang memberi tafsiran yang sangat terhad dan hanya menekankan kepada aspek hukum semata-mata sedangkan ia adalah sesuatu yang merangkumi aspek yang lebih luas dari kerangka sistem perundangan sahaja. ${ }^{21}$ Menurut Aḥmad al-Raysūnī, pendekatan maqāṣid alsharī'ah memerlukan empat aspek yang perlu diberi perhatian dan antaranya ialah menarik kebaikan dan menolak keburukan yang mana aspek ini memberi panduan bahawa sesuatu yang memberi kebaikan, maka ia akan diterima dan diambil kira manakala jika memberi keburukan patut dicegah. ${ }^{22}$

Empat intipati utama telah dirujuk sebagaimana huraian oleh fuqaha Islam dalam menjamin kepentingan manusia dan masyarakat, iaitu mencapai kepentingan di dalam kehidupan (jalb al-mașāliḥ), menolak kerosakan yang bakal timbul dalam kalangan masyarakat (dār al-mafāsid), menyekat

19 Mohd Anuar Ramli, Saiful Islam Nor Mohd Zulkarnain, Mohammad Fuad Mohd Rozib dan Mohd Farhan Md Ariffin, 'Pemakaian Maqasid al-Syariah sebagai Seismograf dalam Penilaian Isu Semasa,' dalam Maqasid al-Shari'ah Konsep dan Pendekatan, ed. Noor Naemah Abdul Rahman, Abdul Karim Ali \& Ridzwan Ahmad (Kuala Lumpur: Jabatan Fiqh dan Usul, Akademi Pengajian Islam, Universiti Malaya, 2016), 126.

20 Mohamad Zaidi Abdul Rahman, 'Aplikasi Maqasid al-Syari' ah dalam Pentadbiran Negara: Satu Tinjaun Sejarah Islam,' Jurnal Fiqh, vol. 12 (2015): 29-56.

21 Jabatan Kemajuan Islam Malaysia, Indeks Syariah Malaysia: Model Tadbir Urus Berteraskan Maqasid Syariah (Putrajaya: Jabatan Kemajuan Islam Malaysia, 2015), 11.

22 Al-Raysūn̄̄, Nazariyat al-Maqāsid 'inda al-Imām al-Syātibi (Virginia: The International Institute of Islamic Though, 1995),40-5. 
kepentingan buruk (sadd al-dharar) dan mementingkan faktor peredaran zaman (taghayyur al-zaman). ${ }^{23}$ Intipati tersebut kesemuanya bertujuan untuk memelihara kemaslahatan (kepentingan) masyarakat yang telah dipisahkan kepada tiga peringkat kepentingannya iaitu, maṣlahah asas (darūriyyah) mașlahah yang diperlukan (hâjizyyāt) dan mașlaḥah yang dituntut oleh maruah (tahsiniyyāh). Ketiga-tiga peringkat kepentingan ini terbahagi pula kepada tiga bahagian, iaitu kepentingan awam masyarakat terbanyak, kepentingan orang kebanyakan dan kepentingan orang perseorangan. ${ }^{24}$ Berdasarkan pengukuran ke atas lima kualiti hidup utama iaitu perumahan, alam sekitar, kesihatan, keselamatan, pengangkutan dan komunikasi, kajian ini melihat keberkesanan tadbir urus MPJ dalam kerangka prinsip pemeliharaan dan matlamat maqāssid alsharī'ah. Dalam konteks ini, perkara penting yang dilihat adalah dua kelompok iaitu Kerajaan Tempatan (pembuat dasar) dan masyarakat (penerima manfaat).

\section{PENGERTIAN KUALITI HIDUP}

Pengertian kualiti hidup tidak boleh ditafsirkan secara umum, hal ini kerana tanggapan kualiti hidup itu sendiri adalah bersifat subjektif dan mempunyai pelbagai dimensi. Oleh kerana perkara yang dirujuk melalui kualiti hidup ini adalah manusia, maka sudah tentu terdapat perbezaan persepsi kualiti hidup itu sendiri. Samruhaizad Samian, menjelaskan perbezaan tersebut boleh dilihat dari sudut persepsi kesihatan individu yang mungkin berbeza menurut umur, jantina dan tempat tinggal atau lingkungannya. ${ }^{25}$ World Health Organization dalam kenyataannya menjelaskan, kualiti hidup adalah tanggapan individu mengenai kedudukan mereka dalam kehidupan iaitu konteks sistem budaya dan nilai di mana mereka tinggal dan berkait rapat dengan tujuan, harapan, tahap serta kebimbangan. ${ }^{26}$ Oleh itu, pengertian kualiti hidup perlu dilihat dari hal-hal yang lebih terperinci. Menurut Grant et al., cara bagaimana kualiti hidup itu didefinisikan boleh ditentukan melalui perkara-perkara spesifik yang turut termasuk di dalam instrumen penilaian. ${ }^{27}$ Kualiti hidup menurut

23 Jabatan Kemajuan Islam Malaysia, Indeks Syariah Malaysia,16.

24 Rahimin Affandi Abdul Rahim, 'Pendekatan Baru Maqasid al-Shariah dalam Pengajian Syariah di Malaysia: Satu Analisis,' Jurnal Fiqh, vol. 3 (2006): 35-80.

25 Samruhaizad Samian, Jamaluddin Md. Jahi \& Azhan Awang, 'Isi Perbandaran dan Kualiti Hidup Penduduk Pinggir Bandar,' Journal of Malay World and Civilisation, vol. 2/1 (2014): 63-75.

26 World Health Organization (WHO), WHO-QOL Study Protocol: The Development of the World Health Organization Quality of Life Assessment Instrument (Geneva: World Health Organization, 1993), 4.

27 Grant, M., Ferell, B.R. \& Hassey Dow, K., 'Measurement of the Quality of Life in Cancer Survivors,' Journal of Nursing and Education, vol. 4 (1995): 523-531. 
IKHM 1999, adalah merupakan sesuatu yang melibatkan perubahan dalam kalangan masyarakat dan sistem sosial daripada keadaan yang dianggap tidak memuaskan kepada keadaan yang lebih baik. ${ }^{28}$ Selain itu, kualiti hidup menurut Haryati Shafii, ialah sesuatu yang merangkumi bukan sahaja pembangunan ekonomi tetapi juga meliputi aspek lain seperti sosial, psikologi, kebudayaan, politik dan alam sekitar. ${ }^{29}$ Seterusnya menurut Wan Maznah et al, kualiti hidup merupakan konsep dinamik berubah mengikut ruang dan masa, hal ini berikutan keperluan dan keinginan manusia semakin kompleks serta berubah mengikut gaya hidup. ${ }^{30}$ Manakala Mahadzirah Mohamad et al, memberi tafsiran kualiti hidup dalam konteks Islam merujuk kepada kehidupan yang baik serta kejayaan mencapai kebahagiaan dalam kehidupan sebagai seorang Muslim. ${ }^{31}$

Rangkuman daripada pengertian kualiti hidup yang diberikan oleh para penyelidik di atas, matlamat yang sebenarnya ingin dicapai adalah sama iaitu mencari jalan penyelesaian dalam memberikan kehidupan yang paling sempurna serta berkualiti kepada semua. Tuntasnya, dapat disimpulkan bahawa kualiti hidup adalah sesuatu yang memberi kebahagiaan, kesempurnaan dan kepuasan hati individu atau kumpulan manusia yang mengalaminya.

\section{PETUNJUK KUALITI HIDUP MALAYSIA 2011}

Indeks Kualiti Hidup Malaysia (IKHM) 2011 adalah merupakan komposit indeks yang merangkumi 11 bidang yang berkait rapat dengan konsep kualiti hidup. Laporan ini juga adalah merupakan laporan yang menganalisis akan perubahan tahap kualiti hidup penduduk Malaysia yang berdasarkan IKHM 1999 sebagai asas. ${ }^{32} 11$ bidang tersebut termasuklah pendidikan, pengangkutan

28 Unit Perancang Ekonomi Jabatan Perdana Menteri, Indeks Kualiti Hidup Malaysia 1999 (Putrajaya: JPM, 1999).

29 Haryati Shafii, Keselesaan Penduduk ke Tempat Bekerja Mempengaruhi Kualiti Hidup Masyarakat di Bandar (Johor: Penerbit UTHM, 2011), 2.

30 Wan Maznah Wan Harun, Azhan Awang \& Shamsuddin Man, 'Kualiti Hidup dan Tahap Pendidikan Isi Rumah di Pinggir Bandar di Malaysia: Satu Penerokaan Isi Rumah di Mukim Rawang II, Selangor,' Journal of Society and Space, vol. 12/9 (2016): 92-103.

31 Mahadzirah Mohamad, Nizaita Omar, Nor Azman Mat Ali dan Zainudin Awang, Penerokaan Pengukur Kualiti Hidup Maqasid Syariah (Kuala Terengganu: Universiti Sultan Zainal Abidin, 2016), 19-20.

32 Unit Perancang Ekonomi Jabatan Perdana Menteri, Indeks Kualiti Hidup Malaysia 2011 (Putrajaya: UPE, JPM, 2012), 2-55. 
dan komunikasi, perumahan, kebudayaan dan hiburan, pendapatan dan pengagihan, keselamatan awam, kesihatan, penyertaan sosial, alam sekitar, kehidupan berkeluarga dan persekitaran kerja. Selain itu, indeks ini juga telah menggunakan 45 pengukur atau indikator yang merangkumi semua bidang tersebut.

\section{METODOLOGI KAJIAN}

Kaedah kualitatif iaitu temu bual, dokumentasi dan pemerhatian telah digunakan dalam kajian ini bagi mendapatkan data. Dalam kajian ini, kaedah yang digunakan oleh pengkaji boleh dilihat melalui rajah di bawah:

Rajah 1: Metodologi Kajian

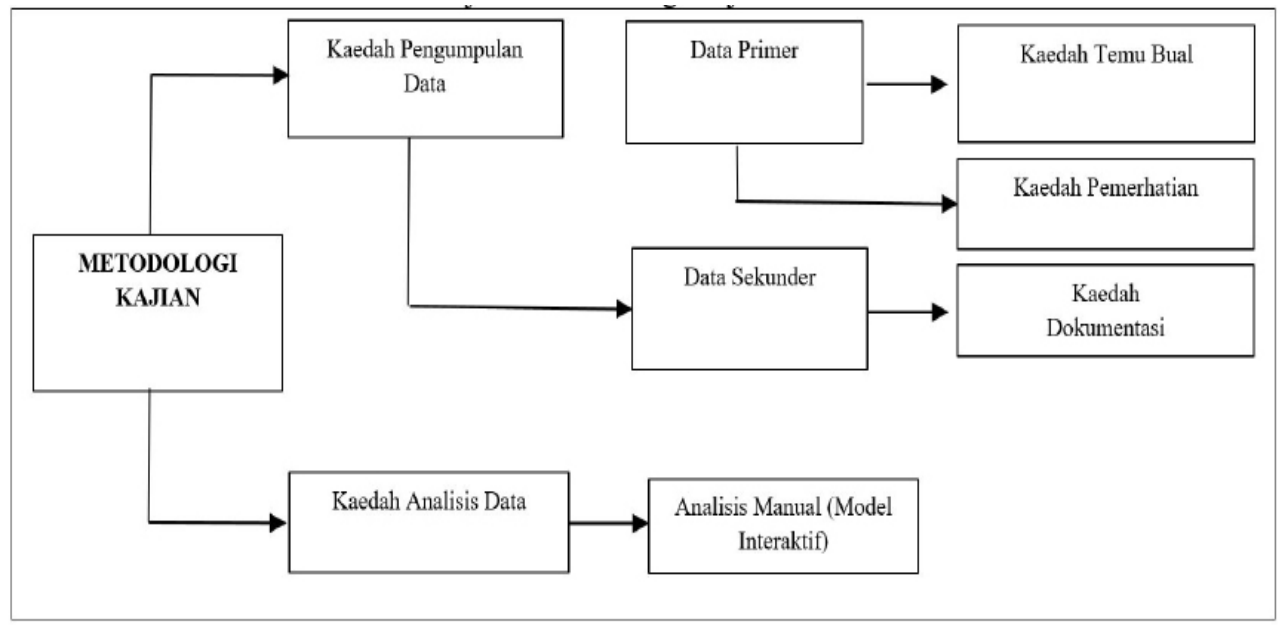

Sumber: Diubahsuai daripada Sabitha Marican. ${ }^{33}$

Untuk kaedah temu bual, pendekatan temu bual semi berstruktur digunakan bagi mendapatkan data dan maklumat yang diperlukan dalam permasalahan kajian. Dengan menggunakan temu bual ini, pengkaji tidak terikat untuk mengetahui jawapan formal yang lebih mendalam yang telah diajukan dan pengkaji bebas mengemukakan soalan lain sekiranya perlu. ${ }^{34}$ Jika jawapan yang diberikan informan masih tidak mencukupi, pengkaji akan

33 Sabitha Marican, Kaedah Penyelidikan Sains Sosial (Selangor: Pearson Sdn. Bhd, 2005). 75.

34 Chua Yan Piaw, Kaedah Penyelidikan (Kuala Lumpur: MC Graw Hill Education, 2014). 114. 
mengajukan soalan tambahan kepada informan. ${ }^{35}$ Fleksibiliti dalam temu bual ini yang membolehkan soalan diubahsuai untuk memahami fenomena yang dikaji. Pemilihan informan untuk kajian ini adalah menggunakan kaedah persampelan yang bertujuan berdasarkan kesesuaian jawatan yang dipegang dan matlamat penyelidikan untuk meneliti isu-isu berkaitan dan tadbir urus PBT terhadap kualiti hidup penduduk. Untuk mengaplikasikan kaedah ini, pendekatan temu bual dijalankan bersama dua orang kakitangan MPJ yang berautoriti memberikan maklumat terperinci tentang tadbir urus MPJ yang menyentuh tentang bidang kuasanya terhadap kualiti hidup penduduk. Dalam masa yang sama, pengkaji turut menjalankan temu bual bersama enam orang informan yang berautoriti. Mereka merupakan wakil penduduk dalam kawasan pentadbiran MPJ, iaitu Asahan, Rim, Bemban, Merlimau, Sungai Rambai dan Serkam. Proses pengumpulan data temu bual ini mengambil masa selama tiga bulan bermula Oktober hingga Disember 2019. Tempoh tersebut adalah berdasarkan kepada gantt chart pengkaji untuk menyiapkan kajian ini. Tempoh pengumpulan data ini adalah berdasarkan kepada kerjasama dan kelapangan masa informan yang terlibat. Anggaran masa yang diambil oleh pengkaji semasa temu bual dilaksanakan adalah 30 hingga 40 minit.

Sewaktu menjalankan temu bual, pengkaji akan membuat rakaman audio dengan keizinan daripada pihak informan. Rakaman ini akan dapat membantu mengatasi masalah ingatan dan membolehkan penelitian yang lebih mendalam terhadap apa yang diperkatakan oleh informan. Seterusnya bagi kaedah dokumentasi pula, data dan fakta diperolehi dengan cara membuat penelitian terhadap dokumen tersebut. Beberapa buah perpustakaan telah dikunjungi, antaranya seperti Perpustakaan Utama Universiti Malaya, Perpustakaan Akademi Pengajian Islam Universiti Malaya, Perpustakaan Negara Malaysia dan Perpustakaan Negeri Melaka untuk mendapatkan bahan-bahan rujukan. Manakala untuk kaedah pemerhatian pula, pemerhatian penuh (complete observer) dijalankan di kawasan kajian. Perlaksanaan kaedah ini adalah secara berperingkat dan ia mengambil masa selama tempoh sebulan. Kebiasaannya, data yang dikumpulkan melalui kaedah pemerhatian ini mempunyai kebolehpercayaan yang tinggi sekiranya dilakukan secara teratur dan dalam situsi kajian yang sebenar. ${ }^{36}$ Pengumpulan data dengan menggunakan kaedah pemerhatian ini juga memerlukan pengkaji untuk mempertimbangkan beberapa perkara seperti siapa yang memerhati, apa yang diperhati, mengapa pemerhatian tersebut dilakukan, di mana pemerhatian dilaksanakan, bila pemerhatian dan berapa lama pemerhatian dilakukan serta bagaimana pemerhatian akan dicatat atau direkodkan. Sewaktu pertimbangan perkara-perkara berikut, pengkaji

35 Syed Ismail Syed Mustapa, Ismail Raduan \& Bushro Ali, Asas Penyelidikan dalam Pendidikan (Petaling Jaya: Sasbadi Sdn Bhd, 2018), 284.

36 Syed Ismail Syed Mustapa, Ismail Raduan, Asas Penyelidikan, 285. 
perlu memikirkan prosedur yang perlu dipatuhi bagi memastikan pemerhatian tersebut dapat dipercayai dan data yang diperolehi ada kesahihannya. ${ }^{37}$

\section{PENGURUSAN MAJLIS PERBANDARAN JASIN (MPJ) TERHADAP KUALITI HIDUP PENDUDUK MENGIKUT BIDANG KUASA}

Peranan Majlis Perbandaran Jasin (MPJ) bagi menentukan kualiti hidup penduduk terkawal dan terjamin adalah melalui perlaksanaan dan penguatkuasaan Akta Induk. Berdasarkan peruntukan yang terdapat dalam Akta 171, Akta 172 dan Akta 133, fungsi MPJ terbahagi kepada lima bidang utama, iaitu:

Jadual 1: Akta Pihak Berkuasa Tempatan (PBT)

\begin{tabular}{|c|c|c|}
\hline Bil. & Item & Fungsi \\
\hline 1. & $\begin{array}{l}\text { Kebersihan Alam } \\
\text { Sekitar }\end{array}$ & $\begin{array}{l}\text { - Pengindahan Kawasan dan Jalan-Jalan Utama } \\
\text { - Penyediaan dan Penyelenggaraan Kawasan Rekreasi } \\
\text { - Pemantauan dan Penyelenggaraan Kawasan Lapang }\end{array}$ \\
\hline 2. & Kesihatan Awam & $\begin{array}{l}\text { - Kawalan Perlesenan Premis Perniagaan } \\
\text { - Kawalan Kebersihan Premis Makanan } \\
\text { - Kawalan Kebersihan Ladang Ternakan } \\
\text { - Kawalan Vektor Dan Rodensia } \\
\text { - Kawalan Binatang Liar Dan Terbiar }\end{array}$ \\
\hline 3. & Sosial & $\begin{array}{l}\text { - Program-program Kemasyarakatan } \\
\text { - Program Bandar Selamat } \\
\text { - Program Bantuan Bencana Alam } \\
\text { - Program Local Agenda } 21 \\
\text { - Program Bandar Mampan }\end{array}$ \\
\hline 4. & $\begin{array}{l}\text { Kemudahan Awam \& } \\
\text { Infrastruktur }\end{array}$ & $\begin{array}{l}\text { - Menyediakan dan Menyelenggara Kemudahan Awam } \\
\text { - Menyediakan dan Menyelenggara Infrastruktur }\end{array}$ \\
\hline 5. & Pembangunan & $\begin{array}{l}\text { - Mengawal Pembangunan Melalui Rancangan Struktur \& } \\
\text { Rancangan Tempatan } \\
\text { - Mengawal dan Menguatkuasa Kelulusan Pelan } \\
\text { Pembangunan } \\
\text { - Mengawal dan Menguatkuasa kelulusan Pelan Kerja Parit } \\
\text { - Mengawal dan Menguatkuasa Pengurusan Jalan \& Parit } \\
\text { - Mengawal dan Menguatkuasa Kelulusan Lampu Awam } \\
\text { - Mengawal dan Menguatkuasa Permit Bangunan } \\
\text { Sementara }\end{array}$ \\
\hline
\end{tabular}

37 Syed Ismail Syed Mustapa, Ismail Raduan \& Bushro Ali, Asas Penyelidikan dalam Pendidikan, 285. 
Sumber: Portal Majlis Perbandaran Jasin. ${ }^{38}$

\section{ANALISIS TINDAKAN MAJLIS PERBANDARAN JASIN (MPJ) TERHADAP ISU KUALITI HIDUP PENDUDUK}

\section{Analisis Isu Kualiti Hidup Penduduk}

\section{Jadual 2: Isu Kualiti Hidup Penduduk}

\begin{tabular}{|c|c|c|}
\hline Bil. & $\begin{array}{c}\text { Pengukur Kualiti } \\
\text { Hidup }\end{array}$ & Isu \\
\hline 1. & Perumahan & $\begin{array}{l}\text { - Pembangunan perumahan kos rendah dan sederhana yang } \\
\text { tidak mencukupi } \\
\text { - Perumahan terbiar } \\
\text { - Kurangnya penyertaan komuniti dalam perancangan, } \\
\text { pengurusan, pengindahan dan keselamatan kawasan } \\
\text { perumahan } \\
\text { - Letakan kenderaan berat di kawasan taman perumahan } \\
\text { - Pembiaran kenderaan lama di kawasan letakan kereta } \\
\text { taman perumahan }\end{array}$ \\
\hline 2. & Alam sekitar & $\begin{array}{l}\text { - Penggunaan racun serangga yang berlebihan boleh } \\
\text { menyebabkan masalah "bioaccumulation" dalam rantaian } \\
\text { makanan melalui sistem kehidupan dalam air } \\
\text { - Pencemaran sungai disebabkan aktiviti pertanian, } \\
\text { penternakan dan perindustrian } \\
\text { - Kawasan rekreasi perlu disediakan bagi memudahkan } \\
\text { aktiviti riadah } \\
\text { - Kemudahan padang dan kawasan lapang tidak diselenggara } \\
\text { - Pembuangan sampah merata-rata tempat }\end{array}$ \\
\hline 3. & Kesihatan & $\begin{array}{l}\text { - Masalah rodensia dan wabak } \\
\text { - Premis makanan kotor } \\
\text { - Perkhidmatan kesihatan yang tidak mencukupi } \\
\text { - Longkang tersumbat } \\
\text { - Anjing liar berkeliaran }\end{array}$ \\
\hline
\end{tabular}

38 Laman Sesawang Majlis Perbandaran Jasin, http://www.mpjasin.gov.my/, dicapai 10 Disember 2019. 


\begin{tabular}{|c|c|c|}
\hline Bil. & $\begin{array}{c}\text { Pengukur Kualiti } \\
\text { Hidup }\end{array}$ & Isu \\
\hline 4. & Keselamatan & $\begin{array}{l}\text { - Jarak Balai Polis dengan penempatan penduduk jauh } \\
\text { - Infrastruktur Balai Polis sedia ada kurang memuaskan } \\
\text { - Penyediaan Pondok Polis perlu mengambil kira pelbagai } \\
\text { aspek } \\
\text { - Kes kecurian } \\
\text { - Penggunaan alat kawalan keselamatan (CCTV) di bandar } \\
\text { perlu diperluaskan } \\
\text { - Risiko kemalangan pejalan kaki } \\
\text { - Kurangnya pencahayaan dibeberapa kawasan berpontensi } \\
\text { untuk dijadikan pusat kegiataan jenayah }\end{array}$ \\
\hline 5. & $\begin{array}{l}\text { Pengangkutan \& } \\
\text { Komunikasi }\end{array}$ & $\begin{array}{l}\text { - Kesesakan lalulintas } \\
\text { - Kekurangan kemudahan pejalan kaki } \\
\text { - Kemudahan tempat letak kereta yang kurang } \\
\text { - Kemudahan pengangkutan awam perlu diperluaskan } \\
\text { - Jadual laluan bas yang tidak menentu } \\
\text { - Hentian-hentian bas kurang } \\
\text { - Lokasi perhentian penumpang kurang memuaskan } \\
\text { - Keadaan jalan sempit }\end{array}$ \\
\hline
\end{tabular}

Sumber: Olahan Pengkaji

Berdasarkan jadual di atas, terdapat pelbagai isu yang melibatkan kualiti hidup penduduk. Antaranya daripada aspek perumahan, antara isu yang melanda penduduk adalah kurangnya pembangunan perumahan kos rendah dan sederhana untuk golongan B40. Hasil dari maklumat yang diperolehi daripada penduduk yang ditemu bual, penawaran perumahan kos rendah dan sederhana masih tidak mencukupi untuk menampung keperluan penduduk terutamanya di Kawasan Rim. Justeru, penawaran perumahan kos rendah dan sederhana terutamanya oleh sektor swasta perlu dipertingkatkan bukan sahaja untuk menampung 'backlog' permintaan, bahkan untuk menampung permintaan baru. Selain itu, penduduk turut mengalami masalah daripada segi perumahan terbiar. Keadaan rumah yang terbiar seperti dipenuhi semak samun akan mengundang kehadiran haiwan berbisa seperti ular. Serta pada masa yang sama, penduduk turut mengalami masalah untuk meletakkan kenderaan berat di kawasan taman perumahan. Sebagai contoh lori dan bas. Pemilik kenderaaan tersebut bukan sahaja meletakkan kenderaan di tepi jalan, malah meletakkannya di taman perumahan dan menimbulkan masalah kekurangan tempat letak kereta.

Dari aspek alam sekitar pula, penduduk mengalami isu pencemaran air yang diakibatkan daripada penggunaan racun serangga yang berlebihan. Hal ini 
boleh menyebabkan berlakunya masalah "bioaccumulation" iaitu penjejasan terhadap rantaian makanan sistem kehidupan dalam air. Dua buah sungai iaitu Sungai Kesang dan Sungai Chin Chin juga mengalami pencemaran air yang disebabkan oleh aktiviti pertanian, penternakan dan perindustrian. Kawasan lapang dan lain-lain kemudahan rekreasi juga perlu disediakan oleh MPJ untuk kemudahan aktiviti riadah selain bertujuan untuk melahirkan kualiti hidup masyarakat yang selesa dan sejahtera. ${ }^{39} \mathrm{Hal}$ ini adalah kerana kawasan rekreasi berfungsi untuk aktiviti aktif dan pasif. Isu pembuangan sampah di merata-rata tempat dan bukan di tempat yang sepatutnya turut berlaku. ${ }^{40}$ Keadaan ini menyebabkan timbulnya masalah kesihatan terhadap masyarakat sekeliling. Jika perkara ini dibiarkan, ia bukan sahaja memberikan kesan kesihatan malah menyebabkan keadaan sekeliling busuk dan kelihatan seperti kawasan longgokan sampah.

Seterusnya dari aspek kesihatan, terdapat masalah penularan wabak rodensia dan aedes yang berlaku dan semakin meningkat. Sikap sesetengah pengusaha premis makanan dan penjaja adalah merupakan salah satu penyebab pembiakan tikus di kawasan perniagaan mereka sukar dikawal. Pada waktu yang sama penduduk turut berdepan masalah kehadiran anjing liar di kawasan taman perumahan. Anjing-anjing tersebut dilihat semakin hari semakin bertambah sejak kebelakangan ini. Ekoran itu penduduk bimbang mengenai kemungkinan digigit oleh anjing liar tersebut dan menyebabkan penularan wabak rabies. ${ }^{41}$ Selain itu, perkhidmatan kesihatan yang disediakan oleh MPJ juga dikatakan tidak mencukupi bagi menampung keperluan penduduk dan kemudahan kesihatan di kawasan luar bandar terutamanya kemudahan asas di klinik luar bandar jauh ketinggalan berbanding di bandar. ${ }^{42}$ Penduduk turut mengalami masalah kekurangan personel-personel perubatan seperti Doktor dan Pembantu Perubatan juga menyebabkan penduduk tidak dapat menerima perkhidmatan kesihatan sebaiknya. Tambahan lagi, kawasan longkanglongkang di sekitar kawasan penduduk juga bermasalah kerana tersumbat. Longkang yang tersumbat akan mengakibatkan banjir kilat kerana ia tidak mampu menampung jumlah air hujan.

39 Hairudin Hj Laili (Wakil Penduduk, Dun Bemban), dalam temu bual bersama pengkaji pada 30 November 2019.

40 Zulkifli Mohd Tahir (Wakil Penduduk, Dun Merlimau), dalam temu bual bersama pengkaji pada 19 Oktober 2019.

41 Muhamad Harun (Wakil Penduduk, Dun Serkam), dalam temu bual bersama pengkaji pada 20 Oktober 2019.

42 Mohd Liza Husain (Wakil Penduduk, Dun Asahan), dalam temu bual bersama pengkaji pada 20 November 2019. 
Untuk aspek keselamatan, penduduk di beberapa kawasan kediaman turut berhadapan dengan isu jarak rumah dan balai polis yang jauh. Hal ini menyukarkan penduduk untuk membuat laporan atau aduan sekiranya berlaku kecemasan. Infrastruktur balai polis yang sedia ada juga kurang memuaskan kerana kebanyakan dari kemudahan tersebut tidak menepati piawaian terutamanya dari segi keluasan. Selain itu, kurangnya rondaan pihak berkuasa juga turut menyebabkan berlakunya kejadian kecurian di kawasan masjid dan balai raya pada waktu malam. Seterusnya penggunaan kamera litar tertutup (CCTV) di bandar juga perlu diperluaskan lagi di kawasan perumahan yang dikenal pasti berisiko mengalami kejadian jenayah. Sekiranya diperluaskan, ia akan dapat membantu pihak polis menjalankan siasatan dan melakukan tangkapan dengan lebih mudah dan pantas sekiranya berlaku perkara yang tidak diingini. Ketiadaan laluan pejalan kaki yang sepatutnya juga berpotensi menyumbang pengaruh yang besar dalam peningkatan kadar kemalangan yang melibatkan pejalan kaki. ${ }^{43}$ Jika ada kemudahan ini, ia secara langsung akan membantu mengurangkan kadar kemalangan yang melibatkan pejalan kaki. Kurangnya pencahayaan di sesebuah tempat juga akan membahayakan pengguna di kawasan terbabit. Terdapat aduan dari penduduk berkaitan kurangnya pencahayaan di beberapa kawasan sehingga kawasan tersebut berpontensi untuk dijadikan sebagai pusat kegiatan jenayah seperti penagihan dadah, ragut, maksiat, pecah kenderaan dan sebagainya. Sebagai contoh, di kawasan berhampiran Politeknik Merlimau.

Aspek terakhir iaitu aspek pengangkutan dan komunikasi juga turut didapati terdapat isu yang dihadapi penduduk. Salah satunya adalah isu kesesakan lalulintas terutamanya pada waktu puncak yang menyebabkan penduduk di kawasan tersebut mengalami kelewatan untuk ke sesebuah tempat. Keadaan ini biasanya dihadapi penduduk yang menggunakan laluan daripada Merlimau ke Jasin dan Merlimau ke Sungai Rambai. Selain itu, kekurangan kemudahan pejalan kaki. Ini bukan sahaja membahayakan keselamatan, malah turut menghalang kelicinan aliran lalu lintas. Seterusnya, penduduk mengalami kesukaran akibat kawasan meletakkan kereta yang begitu terhad. Ini menyebabkan penduduk terpaksa meletakkan kenderaan sesuka hati di bahu jalan dan mengakibatkan kesesakan lalulintas. Di samping itu, kemudahan pengangkutan awam seperti bas dan juga teksi juga perlu diperluaskan. Laluan perkhidmatan bas tempatan sedia ada juga perlu dipertingkatkan dengan menghubungkan kawasan-kawasan penempatan dengan pusat bandar serta ke kawasan-kawasan pembangunan baru. Kekurangan kekerapan laluan dan jadual perkhidmatan bas yang tidak menentu akan menyukarkan pergerakan

43 Razak Mad Delan (Wakil Penduduk, Dun Sungai Rambai), dalam temu bual bersama pengkaji pada 5 Oktober 2019. 
penduduk. Hentian-hentian bas kurang disediakan di kawasan-kawasan yang mempunyai kepadatan penduduk yang tinggi dan pada waktu yang sama, penduduk turut merungut tentang keadaan jalan yang sempit. Ini menyukarkan pergerakan penduduk untuk ke satu tempat ke tempat yang lain. Keadaan jalan yang sempit turut berpotensi untuk menyebabkan berlakunya kemalangan.

Ringkasnya, isu-isu yang dihadapi penduduk memerlukan pandangan dan perhatian secara menyeluruh daripada MPJ. Semua isu-isu tersebut perlu diberi penekanan dan diambil tindakan sewajarnya oleh PBT bagi memastikan ianya dapat diatasi.

\section{Analisis Tindakan Majlis Perbandaran Jasin (MPJ) Terhadap Isu Kualiti Hidup Penduduk}

Seterusnya, bagi memastikan setiap isu yang diutarakan penduduk hasil daripada temu bual, pengkaji seterusnya mendapatkan maklumat daripada MPJ itu sendiri untuk mengetahui apakah tindakan yang dilakukan terhadap isu-isu yang dihadapi penduduk. Tindakan MPJ adalah seperti jadual di bawah:

Jadual 3: Tindakan MPJ Terhadap Isu Kualiti Hidup Penduduk

\begin{tabular}{|c|c|c|}
\hline Bil. & $\begin{array}{c}\text { Pengukur Kualiti } \\
\text { Hidup }\end{array}$ & Tindakan MPJ \\
\hline 1. & Perumahan & $\begin{array}{l}\text { - Menyediakan perumahan mampu milik bagi menampung } \\
\text { keperluan penduduk } \\
\text { - Kerjasama bersama Lembaga Perumahan Negeri Melaka } \\
\text { - Memperkenalkan skim Rumah belia, Rumah Kos Rendah, } \\
\text { Rumah Harapan dan Rumah Mampu Milik } \\
\text { - Menyelesaikan aduan penduduk berkenaan rumah terbiar } \\
\text { - Operasi kebersihan rumah terbiar dan semak samun } \\
\text { - Hari bertemu pelanggan setiap hari Jumaat bagi mendapatkan } \\
\text { - Sasalah dan aduan penduduk } \\
\text { - Kaluran aduan boleh dibuat melalui media sosial rasmi MPJ } \\
\text { Kompaun terhadap kenderaan berat di taman perumahan }\end{array}$ \\
\hline
\end{tabular}




\begin{tabular}{|c|c|c|}
\hline Bil. & $\begin{array}{c}\text { Pengukur Kualiti } \\
\text { Hidup }\end{array}$ & Tindakan MPJ \\
\hline 2. & Alam sekitar & $\begin{array}{l}\text { - Pengawalan aktiviti pertanian di Bemban Dan Kesang } \\
\text { Pajak(mengawal aktiviti pertanian supaya tidak mendatangkan } \\
\text { impak negatif kepada alam sekitar dengan menggalakkan } \\
\text { penggunaan baja kompas organik) } \\
\text { - Mengawal aktiviti industri (pemantauan berkala) } \\
\text { - Penyediaan kawasan rekreasi dan kawasan lapang } \\
\text { - Perancangan kawasan rekreasi perlu mengambil kira pelbagai } \\
\text { aspek fizikal, sosial, kebudayaan, keselamatan, kumpulan } \\
\text { umur dan golongan kurang upaya } \\
\text { - Penguatkuasaan kompaun } \\
\text { - Kerjasama SWcorp }\end{array}$ \\
\hline 3. & Kesihatan & $\begin{array}{l}\text { - Pengawalan rodensia dan wabak } \\
\text { - Pembinaan perkhidmatan kesihatan } \\
\text { - Pemantauan premis makanan } \\
\text { - Pembersihan longkang } \\
\text { - Pemantauan haiwan liar }\end{array}$ \\
\hline 4. & Keselamatan & $\begin{array}{l}\text { - Operasi PATI bersama Imigresen } \\
\text { - Penambahan pondok Polis (12) dan balai Polis (3) } \\
\text { - Kemudahan infrastruktur Balai Polis ditingkatkan } \\
\text { - Kajian Bandar Selamat } \\
\text { - Penambahan Kamera Litar Tertutup (CCTV) } \\
\text { - Cadangan memperbanyakkan pencahayaan di laluan tertentu } \\
\text { - Penyediaan laluan pejalan kaki } \\
\text { - Kerjasama MPJ dengan Polis untuk membendung aktiviti } \\
\text { tidak sihat }\end{array}$ \\
\hline 5. & $\begin{array}{l}\text { Pengangkutan } \\
\text { Komunikasi }\end{array}$ & $\begin{array}{l}\text { - Memperluas sistem pengangkutan awam } \\
\text { - Mengurangkan masalah kesesakan } \\
\text { - Hentian penumpang dibina mengikut kesesuaian lokasi } \\
\text { - Penambahan kemudahan pejalan kaki }\end{array}$ \\
\hline
\end{tabular}

\section{Sumber: Olahan Pengkaji}

Bagi mengatasi masalah yang melanda penduduk, Majlis Perbandaran Jasin (MPJ) telah menjalankan langkah-langkah yang sewajarnya. Untuk menangani isu dari aspek perumahan, MPJ telah menjalankan perancangan dengan mengambil kira latar belakang sosioekonomi masyarakat bagi menjamin setiap keluarga berkemampuan memiliki sesebuah rumah, secara tidak langsung menyokong serta menjamin keselesaan penduduk di bandar dan desa. Dijangkakan tambahan sebanyak 11,484 unit kediaman diperlukan 
sehingga tahun 2020 bagi menampung pertambahan penduduk dan sebagai sokongan kepada pembangunan-pembangunan lain. Antara pembangunan perumahan yang dilaksanakan ialah beberapa projek perumahan di kawasan terpilih dengan kerjasama Lembaga Perumahan Negeri Melaka iaitu antaranya pembinaan Rumah Pangsa Mampu Milik dan perumahan teres 1 tingkat. $^{44}$ Bagi mengatasi isu rumah terbiar pula, antara tindakan diambil oleh MPJ adalah menghantar notis kepada pemilik rumah tersebut agar menyelenggara kebersihan secara berkala. Sekiranya pemilik tersebut gagal untuk berbuat sedemikian, pihak MPJ sendiri yang akan melakukan pembersihan tersebut dan segala perbelanjaan akan dituntut kepada pemilik rumah tersebut. Jika pemilik masih tidak membayar perbelanjaan tersebut, maka Jabatan Kesihatan Persekitaran akan memulakan tindakan pendakwaan di bawah Seksyen 74 Akta Kerajaan Tempatan 1976.

Hari Bertemu Pelanggan turut diadakan oleh MPJ pada setiap hari Jumaat. Sekiranya terdapat sebarang masalah atau aduan yang ingin disuarakan, penduduk boleh ke MPJ pada hari tersebut. Ini memudahkan urusan aduan penduduk dan mempercepatkan tindakan diambil terhadap aduan yang dibuat. Sekiranya penduduk tidak berkelapangan untuk ke MPJ, penduduk boleh membuat aduan di laman sosial MPJ sahaja. Selain itu, bagi memastikan masalah kekurangan tempat letakan kereta yang dihadapi penduduk, MPJ telah melaksanakan operasi pemeriksaan bersama Suruhanjaya Pengangkutan Awam Malaysia (SPAD) dan pihak Polis bagi tujuan membendung tindakan segelintir pemandu atau pemilik kenderaan berat melebihi satu tan meletakkan kenderaan di kawasan taman perumahan. Pengenaan kompaun turut akan dikeluarkan oleh Anggota Penguatkuasa MPJ terhadap pemilik atas kesalahan halangan di bawah Seksyen 46 Akta Jalan, Parit dan Bangunan (133).

Dari aspek alam sekitar yang disebabkan penggunaan racun serangga yang berlebihan, langkah pengawalan aktiviti pertanian di kawasan Bemban dan Kesang Pajak telah dilaksanakan. MPJ mengguna cara dengan menggalakkan para pengusaha kebun untuk menggunakan baja kompas organik. Ia adalah bagi tujuan memelihara dan memberikan menjaga kepada alam sekitar. Seterusnya bagi menyelesaikan masalah isu pencemaran air yang berlaku akibat buangan industri, pemantauan secara berkala ke atas kilang-kilang tersebut turut dilaksanakan dengan mewujudkan zon kawasan perindustrian. Ia adalah untuk memudahkan kerja-kerja pengawalan dan pemantauan dijalankan. Kawasan rekreasi dan kemudahan padang turut disediakan oleh MPJ bagi memastikan kualiti hidup penduduk terjamin mengikut keperluan penduduk. Di bawah

44 Muhd Shahril Saad (Pegawai Jurutera JPBD, MPJ), dalam temu bual bersama pengkaji pada 20 Disember 2019. 
adalah merupakan keperluan tambahan kawasan rekreasi MPJ sehingga tahun 2020:

Jadual 4: Keperluan Tambahan Kawasan Rekreasi MPJ Sehingga Tahun 2020

\begin{tabular}{|c|c|c|c|c|c|c|c|c|c|}
\hline \multirow{2}{*}{ Tahun } & \multirow{2}{*}{$\begin{array}{l}\text { Bilangan } \\
\text { Penduduk }\end{array}$} & \multicolumn{2}{|c|}{ Lot Permainan } & \multicolumn{2}{|c|}{ Padang Permainan } & \multicolumn{2}{|c|}{ Padang Kejiranan } & \multicolumn{2}{|c|}{$\begin{array}{c}\text { Jumlah Keselu- } \\
\text { ruhan }\end{array}$} \\
\hline & & Bil. & Hektar & Bil. & Hektar & Bil. & Hektar & Bil. & Hektar \\
\hline 2007 & 122,900 & 109 & 21.80 & 5 & 3.00 & 3 & 6.00 & 117 & 30.80 \\
\hline 2010 & 130,850 & 14 & 2.80 & 2 & 1.20 & - & - & 16 & 4.00 \\
\hline 2015 & 174,703 & 34 & 6.80 & 7 & 4.20 & 1 & 2.00 & 42 & 13.00 \\
\hline 2020 & 224,753 & 47 & 9.40 & 12 & 11.40 & 4 & 8.00 & 70 & 28.80 \\
\hline \multicolumn{2}{|c|}{ Jumlah } & 204 & 40.80 & 33 & 19.80 & 8 & 16.00 & - & 76.60 \\
\hline
\end{tabular}

Sumber: Rancangan Tempatan Daerah Jasin. ${ }^{45}$

Untuk mengatasi masalah pembuangan sampah di merata-rata tempat, MPJ telah menguatkuasakan tindakan kompaun terhadap orang ramai dan para peniaga yang suka membuang sampah di merata-rata tempat khususnya tempat awam. Hal ini adalah kerana perbuatan membuang sampah di merata-rata tempat adalah merupakan satu kesalahan di bawah Seksyen 47(1) Akta Jalan, Parit dan Bangunan 1974. Kerjasama bersama Swcorp turut dilaksanakan bagi memastikan tiada lagi sampah-sampah yang dibuang merata-rata tempat dengan cara menyediakan tong sampah di tempat-tempat tertentu.

Seterusnya bagi mengatasi isu-isu kesihatan yang timbul dalam kalangan penduduk seperti rodensia dan tularan wabak, semburan fogging telah dilakukan di kawasan perumahan dan kampung. Ia dikelolakan oleh agensi kerajaan dengan kerjasama MPJ di bawah Unit Kawalan Penyakit Bawaan Vektor dan dilaksanakan sekurang-kurangnya dua kali seminggu pada waktu pagi atau petang. Hal ini kerana pada waktu tersebut nyamuk aedes bergerak aktif untuk menggigit. Kekerapan semburan ini dilakukan berdasarkan kepada laporan kes denggi di kawasan tersebut dan akan dilakukan dalam tempoh 24 jam dan diulangi selepas 7 hingga 10 hari. ${ }^{46}$

MPJ juga turut menjalankan pemantauan terhadap premis-premis perniagaan yang berada di Daerah Jasin. Aktiviti pemeriksaan dijalankan oleh MPJ adalah untuk menilai tahap kebersihan premis berpandukan garis

45 Majlis Perbandaran Jasin, Draf Rancangan Tempatan Daerah Jasin 2020 (Jasin: Majlis Perbandaran Jasin, 2020), Jilid 1.21.

46 Laman Sesawang Unit Kawalan Penyakit Bawaan Vektor, Majlis Perbandaran Jasin, http://www.mpjasin.gov.my/ms, dicapai 20 November 2019. 
panduan dan kriteria yang ditetapkan. Premis makanan yang mencapai tahap kebersihan yang cemerlang diberikan penghargaan berupa sijil gred A dan B sebagai dorongan dan inspirasi kepada pengusaha premis yang lain. Di bawah adalah penggredan dan penguatkuasaan premis makanan:

Jadual 5: Penggredan dan Penguatkuasaan Premis Makanan

\begin{tabular}{ccc}
\hline Gred & Skema Markah & Tindakan \\
\hline A & $80 \%-100 \%$ & Sijil Gred \\
B & $60 \%-79 \%$ & Sijil Gred \\
C & $50 \%-59 \%$ & Premis diambil tindakan penguatkuasaan (Notis/Kompaun) \\
Premis & $<50 \%$ & Premis diambil tindakan penguatkuasaan (Penutupan premis di \\
tidak & & bawah Akta Makanan 1983) \\
sanitari & & \\
\hline
\end{tabular}

Sumber: Jabatan Kawalan Perniagaan, Majlis Perbandaran Jasin. ${ }^{47}$

Bagi memastikan perkhidmatan kesihatan terbaik diterima oleh semua penduduk, satu rancangan penambahan kemudahan kesihatan di kawasankawasan dijalankan seperti jadual di bawah:

Jadual 6: Pembangunan Kemudahan Kesihatan Masyarakat di MPJ

\begin{tabular}{ccccc}
\hline Bil. & Klinik & Lokasi & Luas & Catatan \\
\hline 1. & Klinik Desa Asahan & Pekan Asahan & 0.11 & Naik Taraf \\
2. & Klinik Desa Nyalas & Pekan Nyalas & 2.30 & Naik Taraf \\
3. & Klinik Desa Batang & Pekan Batang Melaka & 2.00 & $\begin{array}{c}\text { Naik Taraf Klinik Desa } \\
\text { Ke Klinik Kesihatan }\end{array}$ \\
4. & Klinik Desa Kesang Tua & Kampung Kesang & 0.23 & Naik Taraf \\
5. & Kuarters Integrasi & Taman Bahagia, Jasin & 0.52 & Bina Kuaters \\
6. & Kuaters Sempang Bekoh & Pekan Sempang & 7.53 & Bina Kuaters \\
7. & Kuaters Merlimau & Pekan Merlimau & 6.43 & Bina Kuaters \\
8. & Kuaters Sungai Rambai & Pekan Sungai Rambai & 7.84 & Bina Kuaters \\
\hline
\end{tabular}

\section{Sumber: Rancangan Tempatan Daerah Jasin. ${ }^{48}$}

Isu longkang tersumbat yang dihadapi penduduk juga diatasi dengan jayanya oleh MPJ. Perlaksanaan aktiviti pembersihan telah berlangsung secara bersama dengan penduduk bagi tujuan memupuk kesedaran penduduk tentang pentingnya menjaga kebersihan kawasan kediaman. Peralatan pembersihan

47 Laman Sesawang Jabatan Kawalan Perniagaan, Majlis Perbandaran Jasin, http:// www.mpjasin.gov.my/ms, dicapai 21 November 2019.

48 Majlis Perbandaran Jasin, Draf Rancangan Tempatan Daerah Jasin 2020, 6. 
disediakan oleh MPJ untuk kemudahan penduduk sewaktu program dijalankan. Selain itu, pada masa yang sama juga pokok-pokok di kawasan sekitar yang mengganggu keselamatan penduduk akan dipangkas atau kaedah pemotongan dahan pokok yang bersistematik dijalankan supaya tidak tumbuh tinggi dan meliar sehingga mengganggu keselamatan dan ekosistem pokok lain. MPJ juga mengambil tindakan bagi menangani masalah haiwan kacau ganggu seperti anjing liar atau ternakan berkeliaran. Ini adalah bagi memastikan tiada sebarang penyakit berjangkit seperti wabak yang melibatkan haiwanhaiwan tersebut. Penangkapan haiwan liar secara berkala turut dilaksanakan di kawasan tersebut.

Di samping itu, isu keselamatan yang dihadapi penduduk seperti isu kebimbangan terhadap kebanjiran warga asing tanpa izin telah melahirkan perasaan tidak selamat ketika berada di luar kawasan kediaman. Bagi memastikan masalah warga asing tersebut dapat ditebat, MPJ telah menjalankan operasi Pendatang Asing Tanpa Izin (PATI) bersama kementerian dan agensi berkenaan seperti Kementerian Dalam Negeri, Polis DiRaja Malaysia dan Agensi Penguatkuasaan Maritim Malaysia. Operasi ini adalah bertujuan untuk membasmi masalah kebanjiran warga asing di Malaysia.

MPJ juga turut merancang untuk pembinaan Balai Polis dan Pondok Polis tambahan yang merangkumi seluruh kawasan Jasin. Jumlah anggaran tambahan Balai Polis yang bakal dibangunkan ialah sebanyak tiga buah, manakala Pondok Polis pula adalah sebanyak 12 buah. ${ }^{49}$ Pembinaan kemudahan ini mengambil kira aspek-aspek penempatan penduduk dan faktor-faktor lain seperti faktor fizikal, sosial, kebudayaan, keselamatan, kumpulan umur dan golongan kurang upaya di sesebuah tempat. Kemudahan Balai Polis yang bakal dibina ini juga dibuat penambahbaikan seperti diperluaskan lagi dan kemudahan dalaman seperti kerusi juga ditambah untuk keselesaan pengguna. Pada masa yang sama juga, MPJ telah melaksanakan kajian Bandar Selamat. ${ }^{50}$ Kajian ini adalah bagi memastikan kawasan bandar bebas daripada pelbagai masalah jenayah, bencana alam, kemerosotan sosial dan kemalangan luar serta dalam bangunan. Lagi, bagi memastikan keselamatan penduduk terjamin pihak MPJ juga telah melaksanakan penambahan kamera litar tertutup (CCTV) di kawasan-kawasan yang berpotensi untuk menjadi tumpuan berlakunya jenayah seperti kecurian, ragut dan samun. Selain itu, pemasangan CCTV juga turut dilakukan di kawasan pusat bandar bagi keselamatan rakyat dan pengunjung

49 Majlis Perbandaran Jasin, Draf Rancangan Tempatan Daerah Jasin 2020, 6.

50 Shamsidah Ismail (Pegawai Perancang Bandar \& Desa, MPJ), dalam temu bual bersama pengkaji pada 19 Disember 2019. 
luar serta kawasan persekolahan juga akan diperluaskan penggunaan kamera litar tertutup (CCTV) bagi meningkatkan keselamatan pelajar di sekolah.

Pada masa yang sama, MPJ turut mengambil inisiatif membina tambahan pejalan kaki, terutamanya di kawasan sekolah. Ini adalah untuk memastikan keselamatan pelajar yang berjalan ke pondok hentian bas atau menunggu ibu bapa selepas waktu persekolahan selamat. Selain itu, perancangan laluan pejalan kaki ini juga adalah bertujuan untuk memberikan kemudahan kepada pengunjung-pengunjung bergerak ke destinasi dengan selamat dan selesa. Selain itu, kemudahan ini juga adalah untuk mengatasi masalah kesesakan yang berlaku akibat daripada penambahan bilangan kenderaan yang tinggi dari masa ke semasa.

Beberapa langkah dalam menangani isu pengangkutan dan komunikasi telah dilaksanakan oleh MPJ. Bagi mengatasi masalah kesesakan yang berlaku, MPJ telah memperluaskan sistem pengangkutan awam. Untuk perkhidmatan bas tempatan juga diperluaskan di dalam Daerah Jasin. Laluan perkhidmatan bas tempatan turut dicadangkan bagi menghubungkan kawasan-kawasan penempatan dengan pusat tumpuan serta ke kawasan-kawasan pembangunan baru dan kekerapan perkhidmatan bas juga dipertingkatkan kepada 20 hingga 30 minit bagi setiap sela masa. Hentian-hentian penumpang di kawasankawasan yang mempunyai kepadatan penduduk yang tinggi dan hentian turut dicadangkan turut disedia di kawasan pembangunan baru yang mempunyai laluan bas dengan jarak 500 meter di antara satu sama lain. Ruang untuk bas berhenti (lay-by) yang lebar perlu disediakan bagi memastikan kelancaran lalu lintas dan mengurangkan risiko kemalangan. Memandangkan penggunaan pengangkutan awam semakin meningkat, penyediaan mod pengangkutan berasaskan rel diperlukan pada masa hadapan. Sistem pengangkutan berintegrasi telah dicadangkan dengan mengadakan terminal dan laluan LRT di kawasan pusat pentadbiran, komersial dan pusat pertumbuhan iaitu dari Bandar Jasin ke Batang Melaka dan Ayer Keroh di Hang Tuah Jaya serta pada waktu yang sama laluan-laluan pejalan kaki turut dibina. Penambahan penyediaan laluan pejalan kaki ini adalah salah satu langkah untuk memperbaiki dan mengawal kualiti alam sekitar di samping mewujudkan interaksi sosial di antara masyarakat.

Dengan setiap langkah yang dilakukan MPJ bagi mengatasi masalahmasalah dihadapi penduduk, pengkaji berpandangan ia adalah wajar dan amat sesuai untuk dilaksanakan bagi memastikan kualiti hidup penduduk berada dalam keadaan baik dan selesa. Namun begitu MPJ seharusnya perlu turut sama turun ke lapangan bagi melawat kawasan pentadbirannya tanpa menunggu aduan dilontarkan penduduk kerana rata-rata penduduk meletakkan amanah 
tersebut adalah salah satu daripada tanggungjawab pentadbir di kawasan mereka.

\section{IMPLIKASI TADBIR URUS MAJLIS PERBANDARAN JASIN (MPJ) DARI PERSPEKTIF MAQ $\bar{A} S I D A L-S H A R \bar{I}^{\circ} A H$}

Tujuan utama syariah tidak boleh dipandang ringan atau tidak diberikan perhatian sewajarnya kerana matlamatnya sangat objektif dan praktikal bagi menjamin kepentingan agama, nyawa, akal, keturunan dan harta umat manusia. Hasil tindakan Majlis Perbandaran Jasin (MPJ) bagi menangani isu berkaitan perumahan, tindakan yang diambil adalah merujuk kepada Rancangan Tempatan Daerah Jasin yang mana telah diperuntukkan jumlah rumah baru yang akan dibina mengikut mukim dan jenis keperluan penduduk dikawasan tersebut seperti Rumah Mampu Milik (RMM), Rumah Kos Rendah, Rumah Belia dan Rumah Harapan. Perancangan yang dijangkakan adalah sebanyak 11,484 unit kediaman. Salah satu projek perumahan yang telah siap dibina adalah Projek Perumahan Rakyat Lipat Kijang. Namun begitu, masih terdapat aduan penduduk di kawasan tersebut yang tidak berjaya memiliki rumah. Dari pemerhatian pengkaji, hal ini adalah disebabkan penduduk tersebut tidak menepati syarat kelayakan miliki rumah tersebut iaitu pemohon hendaklah anak negeri Melaka dan faktor pendapatan juga diambil kira kerana ratarata pemohon mempunyai pendapatan yang melebihi syarat yang ditetapkan. Oleh itu dari perspektif maqāșid al-sharī'ah, MPJ boleh dikatakan telah menjalankan tanggungjawab dengan menyediakan kemudahan perumahan kos rendah kerana ia adalah keperluan asas (darüriyyah) yang diperlukan oleh penduduk demi menjaga kepentingan awam masyarakat terbanyak.

Seterusnya bagi menangani isu berkaitan alam sekitar pula, tindakan MPJ dalam menyelesaikan masalah pencemaran air yang berlaku akibat buangan industri, pemantauan secara berkala ke atas kilang-kilang tersebut turut dilaksanakan dengan mewujudkan zon kawasan perindustrian. Oleh itu menurut perspektif maqāṣid al-sharī'ah, tindakan MPJ ini adalah untuk mendatangkan mașlahah, iaitu kebaikan kepada penduduk di kawasan sekitar supaya pencemaran tersebut dapat dikawal. Ini kerana alam sekitar termasuk dalam keperluan hidup masyarakat yang bersifat darüriyyah daripada segi manfaat dan peranannya. Tanpa alam sekitar yang bersih, manusia sukar untuk menjalani kehidupan yang sempurna. Ia adalah untuk menjaga kepentingan awam masyarakat terbanyak.

Kesihatan merupakan salah satu elemen penting dalam memastikan kelangsungan ibadah dan gerak kerja seharian manusia. Antara nikmat yang 
kita semua rasakan dalam hidup ini pastinya apabila dikurniakan kesihatan yang baik. Nikmat ini pula hendaklah dihargai dengan melahirkan rasa syukur yang sehingga akhirnya nikmat tadi akan dilipat-gandakan oleh Allah SWT. Aspek kesihatan juga turut menjadi tanggungjawab MPJ dalam memastikan kualiti hidup penduduk dalam keadaan baik. Salah satu bidang kuasa MPJ dalam menjaga kesihatan penduduk adalah menjalankan semburan fogging di kawasan perumahan dan kampung yang dilaporkan berlaku penularan jangkitan denggi. MPJ juga turunt bertanggungjawab untuk memastikan tahap kebersihan premis perniagaan mengikut garis panduan yang telah ditetapkan. Ringkasnya tindakan yang diambil oleh MPJ bertepatan dengan kehendak maqāsid al-sharī'ah yang mana penjagaaan kesihatan adalah bertujuan untuk menghilangkan kemudaratan kepada diri sendiri dan tidak memudaratkan orang lain.

Implikasi tindakan MPJ mempengaruhi asas kepentingan (ḍaūriyyah) dalam konteks penjagaan nyawa dan akal. Sekiranya kesihatan terancam maka nyawa juga akan turut terancam lebih-lebih lagi apabila penyakit yang dihidapi adalah daripada jenis penyakit yang berbahaya. Begitu juga dengan kepentingan menjaga akal. Kesempurnaan akal juga terletak pada kesempurnaan kesihatan. Tidak mungkin seseorang itu dapat menggunakan akalnya untuk berfikir dan membuat keputusan dengan baik sekiranya akal dan tubuh badannya tidak sihat.

Bagi isu berkenaan keselamatan, salah satu perancangan MPJ adalah membina 15 buah balai polis dan pondok polis tambahan yang merangkumi seluruh kawasan Jasin. Keputusan perancangan tersebut adalah disebabkan sering terjadinya masalah kecurian dan jenayah. Menurut perspektif maqāṣid al-shari'‘ $a$, tindakan MPJ ini adalah untuk menolak kemudaratan atau menghilangkan kerosakan seperti kejadian kecurian yang berulang kali dan melibatkan kerugian harta benda awam. Harta menjadi asas kepada peningkatan kualiti hidup namun Islam menyarankan agar cara memiliki harta tidak menjurus kepada cara yang merosakkan dan mengundang kemurkaan Allah SWT. Harta juga perlu dilindungi daripada kerosakan dan dari peralihan ke tangan orang lain dengan cara yang tidak sah. Dalam konteks ini, penguatkuasaan harus diambil dengan kadar segera bagi menjamin kepentingan darūriyyah.

Akhir sekali adalah, tindakan MPJ terhadap isu penggangkutan dan komunikasi. Bagi mengatasi isu penduduk, MPJ telah memperluaskan sistem pengangkutan awam. Sebagai contoh kemudahan perkhidmatan bas tempatan telah diperluaskan di dalam daerah Jasin. Hal ini bagi menjadikan aspek ketersampaian dalam pengangkutan awam sesuatu yang boleh dinikmati bersama bagi keperluan urusan seharian masing-masing. Merujuk maqāṣid 
al-sharī'ah, keperluan membangunkan infrastruktur dilihat sebagai alat untuk memajukan ummah. Pemerkasaan pengangkutan awam dapat membina bandar lestari atau bandar hijau malah turut mengurangkan pencemaran alam yang banyak disumbang dari perlepasan karbon atau gas dari kenderaan persendirian dan perdagangan. Dari aspek penjagaan harta, penyediaan infrasuktur yang baik dapat menjimatkan kos seseorang seperti penyediaan pengangkutan awam yang lebih murah berbanding menaiki kenderaan sendiri dari kesan penggunaan bahan api atau bayaran tol dan juga bayaran tempat letak kenderaan.

\section{CADANGAN PENAMBAHBAIKAN DALAM MENJALANKAN TADBIR URUS MAJLIS PERBANDARAN JASIN (MPJ)}

Bagi memastikan tadbir urus Majlis Perbandaran Jasin (MPJ) dalam memberikan perkhidmatan terbaik dapat terhadap kualiti hidup penduduk, terdapat pelbagai cadangan penambaikan yang boleh dilakukan. Bagi kualiti alam sekitar, antara cadangan penambahbaikan yang boleh dilakukan ialah MPJ disarankan untuk mewujudkan kerjasama ke arah keberkesanan pengurusan alam sekitar. Kerjasama yang dimaksudkan di sini ialah kerjasama di antara badan-badan Islam sama ada Badan Kerajaan, Badan Berkanun, Persatuan-Persatuan Islam, Badan Bukan Kerajaan (NGO) dan seumpamanya. Sesungguhnya kerjasama yang ingin dibangunkan itu pada hakikatnya telah mempunyai asas atau ikatan yang cukup kuat bagi semua orang Islam iaitu ikatan akidah. Sekiranya akidah Islam menjadi asas penyatuan kerjasama yang ingin dihidupkan, maka tuntutan dakwah pula yang menjadi tanggungjawab semua orang Islam untuk menjadi pengukuh untuk memantapkan lagi usahausaha kerjasama yang ingin dibangunkan

Seterusnya, cadangan lain ialah untuk kualiti kesihatan pula ialah menjalankan program pemeriksaan kesihatan penduduk yang melibatkan dun di dalam kawasan Jasin. Mengikut saranan pakar perubatan, seseorang individu itu perlu melakukan pemeriksaan kesihatan sekurang-kurangnya dua kali dalam tempoh setahun atau enam bulan sekali. Pemeriksaan kesihatan ini adalah merupakan pemeriksaan yang meliputi tekanan darah, paras gula dalam darah, tahap kolestrol dan sebagainya. Tujuan pemeriksaan ini dibuat adalah untuk memastikan tahap kesihatan penduduk berada dalam keadaan sihat dan dapat mengesan penyakit kronik dengan lebih awal seperti penyakit darah tinggi, kencing manis dan sebagainya. MPJ juga sewajarnya berperanan sebagai tempat rujukan penduduk berkaitan maklumat penjagaan kesihatan di mana MPJ perlu memastikan orang ramai dimaklumkan terutamanya mengenai perkara berkaitan kesihatan awam dan pada waktu yang sama, nasihat daripada 
Jabatan Kesihatan juga boleh diperolehi kerana ia adalah sebahagian daripada usaha untuk mengoptimumkan keupayaan MPJ.

Di samping itu, bagi memastikan kualiti hidup dari aspek keselamatan pula perlaksanaan Program Rukun Tetangga dengan penglibatan pegawai MPJ. Langkah tersebut dapat meningkatkan usaha MPJ untuk mengurangkan kadar jenayah di dalam kawasan pentadbirannya. Selain itu, rondaan bersama di kawasan perumahan juga merupakan salah satu langkah bagi membanteraskan kegiatan jenayah. Malah, MPJ juga disarankan untuk menambah baik spesifikasi CCTV melalui kaedah 'technology refreshment' serta mengkaji semula lokasi sedia ada dengan mengambil kira pandangan pihak polis. CCTV yang digunakan perlu dilengkapi dengan teknologi 'face recognition' (pengenalan wajah) dan akan diselia dari pusat arahan yang perlu diwujudkan untuk menyelaras data bagi tujuan keselamatan. Sebagai contoh, penggunaan CCTV yang dilengkapi teknologi pengenalan wajah ini akan digunakan di semua PBT negeri Selangor. ${ }^{51}$

Bagi kualiti kemudahan infrastruktur, penyediaannya, utiliti dan perkhidmatan pelupusan sisa adalah penting bagi meningkatkan kualiti hidup penduduk. Program-program perlu diusahakan MPJ untuk menangani semua aspek penyediaan kemudahan termasuk lah kualiti perkhidmatan, penyelenggaraan, pengagihan keperluan yang mencukupi dan boleh dipercayai. MPJ juga boleh menyediakan infrastruktur yang berkapasiti tinggi dan terkini dalam membangunkan sebuah kawasan sebagai pusat perdagangan antarabangsa dan menjadikannya agar mampu bersaing dengan pusat-pusat serantau dunia dan antarabangsa lain. Penyediaan infrastruktur telekomunikasi juga perlu bersaing seiring dengan kemajuan teknologi semasa.

Bagi memastikan kualiti perumahan terjamin, MPJ boleh memusatkan inisiatif perumahan mampu milik. Satu badan khas wajar ditubuhkan bagi menerajui inisiatif perumahan mampu milik dalam kalangan agensi-agensi kerajaan dan swasta. Strategi pemusatan ini akan meningkatkan kecekapan perancangan, pelaksanaa dan langkah tindakan. Manfaat lain ialah boleh didapati daripada kewujudan entiti tunggal termasuk lah aktiviti pembinaan yang lebih giat dan kos yang lebih rendah hasil daripada ekonomi. Selain itu, langkah lain yang boleh diambil ialah mengurangkan halangan kos terhadap perumahan mampu milik. Salah satu usaha untuk mengurangkan kos adalah menggunakan kaedah pembinaan yang lebih canggih, mengumpulkan entiti

51 Khairul Azran Hussin dan Norrasyidah Arshad, 'Kerajaan Selangor Perkenal Skim Polis Bantuan Atasi Jenayah', Berita Harian Online, https://www.bharian. com.my/berita/wilayah/2019/11/623854/kerajaan-selangor-perkenal-skim-polisbantuan-atasi-jenayah, dicapai 17 Mac 2020. 
tunggal dan mengurangkan kos pematuhan bagi projek perumahan mampu milik. Pasaran rumah sewa juga perlu dipertingkatkan bagi tujuan untuk memperkukuhkan rangka kerja undang-undang. Ia adalah satu langkah bijak melindungi tuan rumah dan penyewa dan langkah tersebut juga perlu dilaksanakan untuk menebat isu dalam jangka masa yang pendek.

\section{KESIMPULAN}

Berdasarkan perbincangan ini, kualiti hidup tidak terhad kepada sesuatu yang hanya bersifat kepuasan hati seseorang individu sahaja. Bahkan, ia merupakan perkara yang merangkumi faktor-faktor lain seperti pendapatan dan agihan, persekitaran kerja, pengangkutan dan komunikasi, kesihatan, pendidikan, perumahan, alam sekitar, kehidupan keluarga, penyertaan sosial dan keselamatan awam. Pengurusan kualiti hidup juga perlu diselaraskan dengan pengurusan dalam Islam yang mana ia adalah merupakan satu sistem yang menekankan dua elemen penting iaitu kekayaan di muka bumi ini ialah hak Allah SWT dan elemen kedua manusia diamanahkan untuk menjadi pengurus atau khalifah Allah SWT dan perlu berpandukan syariah Islam bagi mengeluarkan produk (output) dengan menggunakan sumber (input) yang sedia ada sama ada manusia atau alam semula jadi. Tidak dinafikan juga peranan tadbir urus yang dimainkan oleh Majlis Perbandaran Jasin (MPJ) dalam usaha memastikan kualiti hidup penduduk berada pada tahap yang baik harus dipuji. MPJ juga perlu memainkan peranan yang lebih proaktif dalam menjalankan amanah yang telah diberikan walaupun usaha yang dibuat ini lebih merujuk kepada garis panduan sahaja, namun ia merupakan usaha yang sepatutnya ada agar setiap penduduk dapat menjalani kehidupan yang lebih baik. Kesan daripada peningkatan kualiti hidup penduduk ini akan menghasilkan pencapaian ekonomi yang kukuh, suasana politik yang stabil, kepimpinan berkesan dan perpaduan di kalangan penduduk dalam menjalani hidup juga akan lebih sejahtera.

\section{RUJUKAN}

'Ālim, Yūsuf Hamīd, al-Maqāṣid al- 'Ammah li al-Sharī'ah al-Islāmiyah (alKharțūm: Dār al-Sudāniyyah, 1997).

Abdul Samat Musa, 'Hak dan Tanggungjawab Rakyat dan Ulil Amri,' dalam Konsep dan Peranan Ulilamri di Malaysia, ed. Abdul Monir Yaacob dan Suzalie Mohamad (Kuala Lumpur: Penerbit Institut Kefahaman Islam Malaysia, 2004). 
Al-Baḍāwī, Yūsuf Aḥmad Muḥammad, Maqāṣid al-Sharī'ah 'inda Ibn Taymiyyah ('Ammān: Dār al-Nafā'is, 2000).

Al-Fāsī, 'Alal, Maqāṣid al-Sharī'ah al-Islāmiyyah wa Makārimuhā (Rabat: Mațābi‘ al-Risālah, 1993).

Alias Azhar, 'Penyelidikan Fatwa dalam Kerangka Maqasid al-Syariah: Satu Tinjauan,' Journal of Islamic Sciences, vol. 20 (2017): 47-65.

Chua Yan Piaw, Kaedah Penyelidikan (Kuala Lumpur: MC Graw Hill Education, 2014).

Grant, M., Ferell, B.R. \& Hassey Dow, K., 'Measurement of the Quality of Life in Cancer Survivors,' Journal of Nursing and Education, vol. 4 (1995): 523-531.

Haryati Shafii, Keselesaan Penduduk Ke Tempat Bekerja Mempengaruhi Kualiti Hidup Masyarakat di Bandar (Johor: Penerbit UTHM, 2011).

Ibn 'Āshūr, Muhammad al-Ṭāhīr, Maqāṣid al-Sharī'ah al-Islāmiyyah (t.t.p.: al-Bașā'ir li al-Intāj al-'Ilmiyyah, 1998).

Jabatan Kemajuan Islam Malaysia, Indeks Syariah Malaysia: Model Tadbir Urus Berteraskan Maqasid Syariah (Putrajaya: Jabatan Kemajuan Islam Malaysia, 2015).

Kamarudin Ngah dan Jamaludin Mustaffa, Ahli Majlis dan Kerajaan Tempatan (Kuala Lumpur: Dewan Bahasa dan Pustaka, 2012).

Khairul Azran Hussin dan Norrasyidah Arshad, 'Kerajaan Selangor Perkenal Skim Polis Bantuan Atasi Jenayah', Berita Harian Online, https://www. bharian.com.my/berita/wilayah/2019/11/623854/kerajaan-selangorperkenal-skim-polis-bantuan-atasi-jenayah, dicapai 17 Mac 2020.

Laman Sesawang Jabatan Kawalan Perniagaan, Majlis Perbandaran Jasin, http://www.mpjasin.gov.my/ms, dicapai 21 November 2019.

Laman Sesawang Majlis Perbandaran Jasin, http://www.mpjasin.gov.my/, dicapai 10 Disember 2019.

Laman Sesawang Unit Kawalan Penyakit Bawaan Vektor, Majlis Perbandaran Jasin, http://www.mpjasin.gov.my/ms, dicapai 20 November 2019.

Mahadzirah Mohamad, Nizaita Omar, Nor Azman Mat Ali dan Zainudin Awang, Penerokaan Pengukur Kualiti Hidup Maqasid Syariah (Kuala Terengganu: Universiti Sultan Zainal Abidin, 2016).

Majlis Perbandaran Jasin, Draf Rancangan Tempatan Daerah Jasin 2020 (Jasin: Majlis Perbandaran Jasin, 2020). 
Mohamad Zaidi Abdul Rahman, 'Aplikasi Maqasid al-Syari'ah dalam Pentadbiran Negara: Satu Tinjaun Sejarah Islam,' Jurnal Fiqh, vol. 12 (2015): 29-56.

Mohd Anuar Ramli, Saiful Islam Nor Mohd Zulkarnain, Mohammad Fuad Mohd Rozib \& Mohd Farhan Md Ariffin, 'Pemakaian Maqasid al-Syariah sebagai Seismograf dalam Penilaian Isu Semasa,' dalam Maqasid alShari'ah Konsep dan Pendekatan, ed. Noor Naemah Abdul Rahman, Abdul Karim Ali \& Ridzwan Ahmad (Kuala Lumpur: Jabatan Fiqh dan Usul, Akademi Pengajian Islam, Universiti Malaya, 2016), 111-136.

Muhammad Nazir Alias, 'Maqasid Syariah Sebagai Sandaran Hukum Menurut Mazhab Syafie,' Journal of Islam and Civilization, vol. 2 (2018): 48-58.

Norain Mod Asri, Zulkefly Abdul Karim, Norlaila Abu Bakar, Zafirah Husin, Harith Hasnan dan Idris Hamid, 'Pengurusan Fiskal Pihak Berkuasa Tempatan yang Berstatus Majlis Bandaraya di Zon Tengah Semenanjung Malaysia,' Jurnal Ekonomi Malaysia, vol. 52 (2018): 77-88.

Rahimin Affandi Abdul Rahim, 'Pendekatan Baru Maqasid al-Shariah dalam Pengajian Syariah di Malaysia: Satu Analisis,' Jurnal Fiqh, vol. 3 (2006): 35-80.

Al-Raysūn̄̄, Nazariyat al-Maqāsid 'inda al-Imām al-Syātibi (Virginia: The International Institute of Islamic Though, 1995).

Al-Raysūn̄i, Naẓariyat al-Maqāsid 'inda al-Imām al-Shātibī (Herndon: alMa'had al-'Alamī li al-Fikr al-Islāmī, 1995).

Sabitha Marican, Kaedah Penyelidikan Sains Sosial (Selangor: Pearson Sdn. Bhd, 2005).

Samruhaizad Samian, Jamaluddin Md. Jahi \& Azhan Awang, 'Isi Perbandaran dan Kualiti Hidup Penduduk Pinggir Bandar,' Journal of Malay World and Civilisation, vol. 2/1 (2014): 63-75.

Syed Ismail Syed Mustapa, Ismail Raduan \& Bushro Ali, Asas Penyelidikan dalam Pendidikan (Petaling Jaya: Sasbadi Sdn Bhd, 2018).

Unit Perancang Ekonomi Jabatan Perdana Menteri, Indeks Kualiti Hidup Malaysia 1999 (Putrajaya: UPE, JPM, 1999).

Unit Perancang Ekonomi Jabatan Perdana Menteri, Indeks Kualiti Hidup Malaysia 2011 (Putrajaya: UPE,JPM, 2012).

Wahbah al-Zuhaylī, Ușūl Fiqh al-Islāmī, vol. 2 (Dimashq: Dār al-Fikr, 1996).

Wan Maznah Wan Harun, Azhan Awang \& Shamsuddin Man, 'Kualiti Hidup dan Tahap Pendidikan Isi Rumah di Pinggir Bandar di Malaysia: Satu Penerokaan Isi Rumah di Mukim Rawang II, Selangor,' Journal of Society and Space, vol. 12/9 (2016): 92-103. 
World Health Organization (WHO), WHO-QOL Study Protocol: The Development of the World Health Organization Quality of Life Assessment Instrument (Geneva: World Health Organization, 1993).

\section{Statut}

Akta Jalan, Parit dan Bangunan 1974, (Akta 133).

Akta Kerajaan Tempatan 1976, (Akta 171).

Akta Perancangan Bandar dan Desa 1976, (Akta 172).

\section{Temu bual}

Hairudin Hj Laili (Wakil Penduduk, Dun Bemban), dalam temu bual bersama pengkaji pada 30 November 2019.

Mohd Liza Husain (Wakil Penduduk, Dun Asahan), dalam temu bual bersama pengkaji pada 20 November 2019.

Muhamad Harun (Wakil Penduduk, Dun Serkam), dalam temu bual bersama pengkaji pada 20 Oktober 2019.

Muhd Shahril Saad, (Pegawai Jurutera JPBD, MPJ), dalam temu bual bersama pengkaji pada 20 Disember 2019.

Razak Mad Delan (Wakil Penduduk, Dun Sungai Rambai), dalam temu bual bersama pengkaji pada 5 Oktober 2019.

Shamsidah Ismail (Pegawai Perancang Bandar \& Desa, MPJ), dalam temu bual bersama pengkaji pada 19 Disember 2019.

Zulkifli Mohd Tahir (Wakil Penduduk, Dun Merlimau), dalam temu bual bersama pengkaji pada 19 Oktober 2019. 